* Doutora em Direito na área de Relações Internacionais pela Universidade Federal de Santa Catarina -UFSC. Mestra em Direito na área de Relações Internacionais pela Universidade Federal de Santa Catarina-UFSC. Docente Direito Público na Universidade Federal de Alagoas. E-mail: alemarchioni@hotmail. com

** Mestre em Direito Público pela Universidade Federal de Alagoas - UFAL. Especialista em Direito Administrativo pela Universidade de Salamanca (ES),

E-mail: damb84@hotmail.com

\section{A "Terceirização" na Administração Pública: \\ o Uso do Direito e dA Linguagem JuRídicA No CONTEXTO do RE $\mathbf{N}^{0} 760.931 / \mathrm{DF}$}

The “Outsourcing” In the Public Sector: the Use of LaW and Legal Meanings of Words in the Context OF THE EXTRAORDINARY APPEAL Nº ${ }^{\circ}$ 760.931/BRAZILIAN FEDERAL District

\section{Alessandra Marchioni* Daniel Miranda Borba**}

Como citar: MARCHIONI, Alessandra; BORBA, Daniel Miranda. A contribuição da análise de custo-benefício na avaliação da eficiência de regras fundiárias do distrito federal. Revista do Direito Público, Londrina, v. 13, n. 3, p. 91-110, dez. 2018. DOI: 10.5433/24157-108104-1.2018v13n3 p. 91. ISSN: 1980-511X.

Resumo: Esse artigo tem como objetivo apontar alguns dos principais elementos da teoria e da prática da "terceirização" das condições laborais do trabalhador, compreendida sob a forma de contratos de gestão ou termos de parcerias para a execução de atividades-meio, depois atividades-fim, entre a Administração Pública e a pessoa jurídica de direito privado, desde um contexto histórico normativo de resultados, tanto do ponto de vista da extensão, quanto da ampliação de seus conteúdos. Além disso, seguindo a perspectiva bourdiana, propõe-se a realizar uma abordagem sobre o Estado e o direito, sua função e seu funcionamento, a partir do uso da linguagem jurídica, especialmente identificada na decisão do RE 760.931/DF. Nessa pesquisa será utilizado o método de abordagem hipotético dedutivo, em que se busca testar a hipótese da "satisfação da eficiência e modernidade" mediante os contratos de terceirização, a partir da demonstração das consequências jurídico-normativas e sociais.

Palavras chaves: Terceirização; Administração pública; Pierre Bourdieu; RE 760931/DF.

Abstract: This article highlights important elements of the theory and practice of "outsourcing" employees and their 
working conditions. Therefore, this paper analyzes management contracts or partnership agreements, enforcement of support services, and replacement of jobs in core activities between public and private entities of Private Law. Moreover, this paper analyzes important consequences of the outsourcing of jobs from a normative and historical context, as well as from various viewpoints of extension and the expansion of this problem in modern-day Brazil. Furthermore, utilizing the Bourdieu approach, this study investigates cautiously the role of the State and Law as instruments needing human interpretation. In light of this, this research analyzes the decision of the Extraordinary Appeal n. 760.931/DF and utilizes the hypothetical-deductive method, whereupon testing the "satisfaction of efficiency and modernity" hypothesis through outsourcing contracts, which have social and legal impacts.

Keywords: Outsourcing. Public Sector; Pierre Bourdieu; Extraordinary Appeal no 760.931/Brazilian Federal District. 


\section{INTRODUÇÃO}

Estudos do Departamento Intersindical de Estatísticas e Estudos Socioeconômicos (DIEESE, 2017) apontam para os inúmeros impactos sociais e econômicos dos chamados contratos “terceirizados" sobre a qualidade de vida do trabalhador e sua família. Entre os resultados estão: a maior taxa da rotatividade dos trabalhadores, o número superior de quantidade de horas trabalhadas e os salários inferiores. Não obstante a isso, observa-se que o número de trabalhadores terceirizados no serviço público federal já alcança $35 \%$ de todas as contratações.

Esse artigo tem como objetivo apontar alguns dos principais elementos da teoria e da prática da "terceirização", compreendida sob a forma de contratos de gestão ou termos de parcerias para a execução de atividades-meio, depois atividades-fim, entre a Administração Pública e a pessoa jurídica de direito privado, a partir de um contexto histórico normativo de resultados, tanto do ponto de vista da extensão, quanto da ampliação de seus conteúdos em relação à precarização das condições laborais do trabalhador.

Além disso, seguindo a perspectiva bourdiana, propõe-se a realizar uma abordagem sobre o Estado e seu metapoder, identificado como o "lugar" em que se concentram os diferentes tipos de poder e de instrumentos de coerção. No mesmo sentido, entende-se que essas análises não podem prescindir de considerações acerca do direito e de suas funções, enquanto mantenedor das relações de poder e agente social catalizador de tais práticas "precarizantes".

Por fim, ainda sobre o direito, pretende-se discorrer sobre algumas espécies de argumentações discursivas, usadas para convencer dos efeitos da decisão do RE $\mathrm{n}^{\mathrm{o}}$ 760.931/ DF, que mais bem dissimulam as relações econômicas, sociais e ambientais desfavoráveis ao hipossuficiente, empregado terceirizado (BRASIL, 2017a).

Nessa pesquisa será utilizado o método de abordagem hipotético dedutivo, em que se busca a eliminação dos erros da hipótese: "a administração pública tornou-se mais "moderna e eficiente" com a adoção das medidas terceirizantes", ao contrário, o texto procurará testar a falsidade dessa proposição, ou seja, a partir da demonstração das consequências jurídico-normativas e sociais.

\section{1 “TERCEIRIZAÇÃO” E ADMINISTRAÇÃO PÚBLICA: HIPÓTESE DE PRECARIZAÇÃO DAS RELAÇÕES DE TRABALHO}

O termo "terceirização" deriva da palavra "terceiro" intermediário ou interveniente. Enquanto no campo da administração empresarial, esse termo aparece associado à ideia de "descentralização das atividades das empresas", no domínio do direito do trabalho, relacionase ao "fenômeno [que] dissocia a relação econômica de trabalho da relação justrabalhista que lhe seria correspondente" ${ }^{2}$. Assim, a tradicional relação bilateral empresa e trabalhador passa a

1 De acordo com Delgado, o neologismo terceirização enfatiza a transferência de parte das atividades de uma empresa para um terceiro, contrapondo-se à clássica centralização destas atividades (DELGADO, 2015, p. 473).

2 Trata-se da inserção do trabalhador no processo produtivo do tomador de serviços, sem, no entanto, configurar o vínculo entre estes dois sujeitos, na medida em que será formado entre o obreiro e a entidade interveniente (DELGADO, 2015, p. 473). 
uma relação trilateral, constituída por este, uma empresa terceirizante e o tomador de serviços ${ }^{3}$. Segundo Delgado (2015), é possível observar um conjunto de "desajustes" nas relações de trabalho, por meio do aumento das situações "precarizadoras", como inadimplemento de direitos, meio ambiente de trabalho precário, discriminação, falta de representação sindical, entre outras, que se contrapõe ao entendimento tradicional sobre a forma de tutela e de distribuição dos direitos e deveres de empregador e empregado.

Adotada no final dos anos sessenta, como modelo alternativo à centralidade da administração pública brasileira, a "terceirização" sempre colecionou um grupo de argumentos doutrinários e jurisprudências em seu desfavor, justamente pelos efeitos perniciosos que passou a causar às relações sócio-laborais. No entanto, nos últimos anos, é possível observar uma mudança daquele ponto de vista em prol do avanço irrestrito de seu uso e prática.

\subsection{A “terceirização" na Administração Pública: limites à proteção do trabalhador}

Apesar das contradições desse modelo administrativo e justrabalhista, a "terceirização" passou a ser adotada de forma recorrente no setor público, pelo menos desde o Decreto-Lei $\mathrm{n}^{\circ}$ 200/19674. Essa lei, depois combinada à Lei no $5.645 / 1970^{5}$, passou a dispor sobre a situação de atividades consideradas meramente executivas ou operacionais, como transporte, conservação, custódia, limpeza entre outras, também chamadas de "atividade-meio", e a possibilidade de serem descentralizadas e cumpridas, através de contratos, pelo setor privado.

Logo em seguida, a Lei n ${ }^{\circ}$ 6.019/1974 previu a possibilidade de “terceirização”, em contratos temporários, "para atender à necessidade transitória de substituição de pessoal regular e permanente ou acréscimo extraordinário de serviços" ". Alguns anos mais tarde, a Lei n 7.102/1983 passou a permitir a modalidade de contrato por "terceirização", essa última referindo-se à contratação de vigilantes em instituições bancárias. Em momento seguinte, ampliou-a para "qualquer tipo de atividade pública ou privada" (BRASIL, 1994).

O regime de concessão e permissão da prestação de serviços públicos na área elétrica (BRASIL, 1995), bem como na área de telefonia (BRASIL, 1997b), foram os primeiros exemplos que autorizaram a transferência de uma atividade pública para a iniciativa privada. Além disso, foram as primeiras hipóteses que ampliaram as contratações de mão de obra interposta para

3 Outra forma de terceirização, desta vez chamada de "publicização", traz uma alternativa ao estatismo, na qual tudo é realizado pelo Estado, e à privatização, em que tudo é reduzido à lógica do mercado e do lucro privado, no que permite a transferência de atividades não exclusivas do Estado para entidades do terceiro setor (BRESSERPEREIRA, 2011, p. 246-247).

4 Art. $10[\ldots]$. $\S 7^{\circ}$ Para melhor desincumbir-se das tarefas de planejamento, coordenação, supervisão e controle e com o objetivo de impedir o crescimento desmesurado da máquina administrativa, a Administração procurará desobrigarse da realização material de tarefas executivas, recorrendo, sempre que possível, à execução indireta, mediante contrato, desde que exista, na área, iniciativa privada suficientemente desenvolvida e capacitada a desempenhar os encargos de execução (BRASIL, 1967).

5 Art. $3^{\circ}[\ldots]$. Parágrafo único. As atividades relacionadas com transporte, conservação, custódia, operação de elevadores, limpeza e outras assemelhadas serão, de preferência, objeto de execução indireta, mediante contrato, de acordo com o artigo 10, $\S 7^{\circ}$, do Decreto-lei número 200, de 25 de fevereiro de 1967. (Revogado pela Lei $n^{\circ} 9.527$, de 1997) (BRASIL, 1970).

6 Essa lei sofreu profundas alterações pela Lei no 13.429/2017, conforme será demonstrado adiante. 
além daquelas ligadas à atividade-meio, e que possibilitaram a contratação de terceiros para o "desenvolvimento de atividades inerentes, acessórias ou complementares ao serviço", "bem como a implementação de projetos associados".

No entanto, a adoção desses novos mecanismos de gestão administrativa e justrabalhista, que permitiram um grande número de "transferência de atividades" do poder público para o setor privado, jamais foram uma unanimidade para os jurisconsultos.

De fato, a expansão dessa solução administrativa ao superar as próprias hipóteses previstas nas leis, passou a gerar uma série de incumprimentos à legislação laboral, seja pela precarização das próprias atividades laborais, seja pelo agravamento das condições do meio ambiente de trabalho. Além disso, essa espécie de contrato possibilitou que a gestão das contratações de pessoal, em certos ramos de atividade, fossem transferidos, parcial ou totalmente, para outras empresas fornecedoras de mão de obra, o que ampliou significativamente a soma de impactos negativos e subgarantias aos direitos dos trabalhadores (CAMPOS, 2016, p. 12) ${ }^{7}$

Nesse cenário, não é incomum estar-se diante de um simulacro, quando se analisa os casos de contrato de "terceirização tradicional" ou de "terceirização de risco" e as suas práticas, ambas buscando garantir a redução de seus custos operacionais, seja com a mão de obra ${ }^{8}$, seja com a transferência de obrigações para terceiros (PRADO apud DI PIETRO, 2015, p. 218-219).

Se bem que com "facetas" específicas, esse panorama também se reproduz nas contratações do serviço público, relações laborais que muitas vezes são caracterizadas pelos chamados "calotes" tanto do setor público, quanto do setor privado. Entre os flagrantes prejuízos às normas trabalhistas estão as condições precárias da atividade desempenhada pelo trabalhador, como a desigualdade de remunerações e de benefícios dos terceirizados. Também a diferença entre o total de horas trabalhadas pelo terceirizado, que conta com rara fiscalização quanto ao uso de equipamentos de proteção e treinamentos contra riscos na atividade laboral, tem levado ao aumento do número de doenças, acidentes e mortes do trabalho (CUT, 2014, p. 21-30).

\subsection{A "terceirização" e a solução do Tribunal Superior do Trabalho: das atividades- meio às atividades-fim}

Nessas circunstâncias, o Tribunal Superior do Trabalho editou a Súmula 2569, a qual dispunha sobre a ilegalidade de qualquer caso de "terceirização" que extrapolasse aqueles previstos na Lei $n^{\circ}$ 6.019/1974 (BRASIL, 1974) e na Lei no 7.102/1983 (BRASIL, 1983). Tal "ilegalidade"

7 Estas preocupações ocorrem nos casos de terceirizações lícitas, quando há uma relação de "parceria" com a transferência de atividades acessórias oriunda da especialização, para que a tomadora de serviços se preocupe tão somente com a sua atividade principal. No entanto, as empresas subterceirizadas, por serem mais precárias, têm maiores dificuldades na observância dos direitos trabalhistas, incluindo mínima sindicalização com efeitos ao próprio resultado da negociação coletiva (CAMPOS, 2016, p. 12).

8 Segundo a Confederação Nacional da Indústria, 91\% das empresas "terceirizam" visando a redução de custos, enquanto apenas 2\% visam a especialização técnica (CUT, 2014, p. 9).

9 CONTRATO DE PRESTAÇÃO DE SERVIÇOS. LEGALIDADE (cancelada) - Res. 121/2003, DJ 19, 20 e 21.11.2003 Salvo os casos de trabalho temporário e de serviço de vigilância, previstos nas Leis $n^{\circ} \mathrm{s} 6.019$, de 03.01.1974, e 7.102, de 20.06.1983, é ilegal a contratação de trabalhadores por empresa interposta, formando-se o vínculo empregatício diretamente com o tomador dos serviços. 
teve o condão de fazer reconhecer o vínculo direto entre o trabalhador e o tomador de serviços.

No entanto, essa Súmula não absorveu todas as situações de contratação terceirizada pela Administração Pública, já que, por vedação constitucional, não é possível realizar tal contratação de trabalhadores sem concurso público (DELGADO, 2015, p. 485).

Nesse sentido, em 1993, o TST preferiu revisar o seu entendimento, e editou a Súmula ${ }^{\circ}$ $331^{10}$, passando a oportunizar e a validar a "terceirização" das chamadas atividades-meio do setor público pelas empresas, desde que o tomador respondesse de forma subsidiária pelo inadimplemento da empresa interposta. Até então, em função da exigência constitucional de concurso público, o vínculo não poderia se estabelecer com o tomador, se este fosse o Poder Público.

Em 1997, uma nova regulamentação buscou especificar o conceito de "atividades-meio" que poderiam ser contratadas pelo regime terceirizado. O Decreto $n^{\circ}$ 2.271/1997 dispôs sobre a contratação de serviços no âmbito da União e previu no artigo $1^{\circ}, \S 1^{\circ}$, que as "atividades de conservação, limpeza, segurança, vigilância, transportes, informática, copeiragem, recepção, reprografia, telecomunicações e manutenção de prédios, equipamentos e instalações serão, de preferência, objeto de execução indireta" (BRASIL, 1997a).

Algum tempo depois, a Lei no 9.637/1998 11 autorizou a "terceirização" de atividades-fim da Administração Pública no tocante aos serviços públicos "não exclusivos", quais sejam os de pesquisa científica, desenvolvimento tecnológico, proteção e preservação do meio ambiente, cultura e saúde, que deverão ser prestadas por entidades do terceiro setor, que recebam a qualificação de organização social, por meio da celebração de um contrato de gestão que definirá obrigações e responsabilidades ${ }^{12}$.

Revendo o posicionamento da Súmula 331, o Supremo Tribunal Federal declarou constitucional o artigo 71 da Lei $n^{0} 8.666 / 1993^{13}$ (ADC $\left.n^{\circ} 16 / D F\right)$, que impedia a automática

10 CONTRATO DE PRESTAÇÃO DE SERVIÇOS. LEGALIDADE (nova redação do item IV e inseridos os itens V e VI à redação) - Res. 174/2011, DEJT divulgado em 27, 30 e 31.05.2011 I - A contratação de trabalhadores por empresa interposta é ilegal, formando-se o vínculo diretamente com o tomador dos serviços, salvo no caso de trabalho temporário (Lei n ${ }^{\circ}$ 6.019, de 03.01.1974). II - A contratação irregular de trabalhador, mediante empresa interposta, não gera vínculo de emprego com os órgãos da Administração Pública direta, indireta ou fundacional (art. 37, II, da CF/1988). III - Não forma vínculo de emprego com o tomador a contratação de serviços de vigilância (Lei ${ }^{\circ}$ 7.102, de 20.06.1983) e de conservação e limpeza, bem como a de serviços especializados ligados à atividade-meio do tomador, desde que inexistente a pessoalidade e a subordinação direta. IV - O inadimplemento das obrigações trabalhistas, por parte do empregador, implica a responsabilidade subsidiária do tomador dos serviços quanto àquelas obrigações, desde que haja participado da relação processual e conste também do título executivo judicial. V - Os entes integrantes da Administração Pública direta e indireta respondem subsidiariamente, nas mesmas condições do item IV, caso evidenciada a sua conduta culposa no cumprimento das obrigações da Lei n. ${ }^{\circ}$ 8.666, de 21.06.1993, especialmente na fiscalização do cumprimento das obrigações contratuais e legais da prestadora de serviço como empregadora. A aludida responsabilidade não decorre de mero inadimplemento das obrigações trabalhistas assumidas pela empresa regularmente contratada. VI - A responsabilidade subsidiária do tomador de serviços abrange todas as verbas decorrentes da condenação referentes ao período da prestação laboral.

11 No mesmo sentido é a Lei $n^{\circ}$ 9.790/1999 (BRASIL, 1999), que trata sobre as organizações da sociedade civil de interesse público.

12 No caso dos serviços públicos não exclusivos como de titularidade do poder público e da iniciativa privada, o Supremo Tribunal Federal entendeu que estas atividades econômicas são de interesse público, passíveis, portanto, de um marco regulatório intermediário, não tão rígido quanto o público, nem tão livre quanto o privado, podendo o Estado fomentar estas atividades através de incentivos e estímulos a comportamentos voluntários, o que colabora com o princípio da consensualidade e da participação (BRASIL, 2015).

13 Art. 71. O contratado é responsável pelos encargos trabalhistas, previdenciários, fiscais e comerciais resultantes da execução do contrato. $\S 1^{\circ} \mathrm{A}$ inadimplência do contratado, com referência aos encargos trabalhistas, fiscais e comerciais não transfere à Administração Pública a responsabilidade por seu pagamento, nem poderá onerar o objeto do contrato ou restringir a regularização e o uso das obras e edificações, inclusive perante o Registro de Imóveis. (Redação dada pela Lei n 9.032, de 1995) (BRASIL, 1993). 
responsabilização do poder público pelo inadimplemento de obrigações trabalhistas contraídas pelas empresas contratadas. Assim, para que haja a responsabilização da Administração Pública será necessária a demonstração da culpa in eligendo, relativa à regularização do procedimento de contratação pública, bem como, em especial, da culpa in vigilando, no tocante à fiscalização das obrigações trabalhistas da empresa terceirizada. ${ }^{14}$

Na mais recente decisão (Recurso Extraordinário n ${ }^{\circ}$ 760.931/DF com repercussão geral), o STF ratificou a $\mathrm{ADC} \mathrm{n}^{\circ}$ 16/DF e aprofundou o problema ao considerar que a Administração Pública não pode ser responsabilizada por dívidas trabalhistas das empresas terceirizadas, cabendo o ônus de comprovar que o ente público agiu com culpa ao trabalhador terceirizado (BRASIL, 2017b).

Um dia após essa decisão, foi aprovada a Lei n ${ }^{0} 13.429 / 2017$, que além de atualizar a lei sobre "trabalho temporário" (BRASIL, 1974), e estendê-lo por até cento e oitenta dias, tanto para atividades-meio, como para atividades-fim da empresa tomadora de serviços ${ }^{15}$, também ampliou as hipóteses de "terceirização" e precarização das relações de trabalho para todas aquelas atividades. ${ }^{16}$

Ainda não há uma posição pacífica sobre as implicações dessa lei no setor público, haja vista a impossibilidade da contratação sem concurso público de "trabalhador temporário", salvo no caso da contratação excepcional no interesse público. Apesar dessa proibição, é possível observar casos em que são firmados contratos sob a "fórmula de prestação de serviços", visando cobrir com aparente legalidade tal contratação, burlando os dispositivos constitucionais referentes à contratação estrita por concurso público.

Atualmente, o percentual de trabalhadores terceirizados realizando atividades laborais no serviço público federal já chega a 35\% (CUT, 2014, p. 47-48).

Os impactos sociais e econômicos dessa forma de contratação são inúmeros. Estudos do Departamento Intersindical de Estatísticas e Estudos Socioeconômicos (DIEESE) de $2014^{17}$ apresentam os seguintes resultados sobre: taxa da rotatividade dos trabalhadores terceirizados, duas vezes maior que os não terceirizados $(57,7 \%$ contra $28,8 \%)$; jornada de trabalho superior aos não terceirizados (85,9\% possuíam contratos entre 41 e 44 horas semanais, contra 61,6\%); salários dos terceirizados em relação aos não terceirizados (em média 23,4\% menor em idênticas condições); índices de acidentes de trabalho dos trabalhadores terceirizados e não terceirizados $(9,6 \%$ contra $6,1 \%)(2017$, p. 23$)$.

Em todo contexto de instalação e ampliação do mecanismo administrativo da "terceirização", verifica-se a presença estatal como agente social catalizador das práticas "precarizantes”, que

14 Recurso Extraordinário $n^{\circ} 760.931 / \mathrm{DF}$ (com repercussão geral), o que aprofundou o problema ao considerar que a Administração Pública não pode ser responsabilizada por dívidas trabalhistas das empresas terceirizadas, cabendo o ônus de comprovar que o ente público agiu com culpa ao trabalhador terceirizado (BRASIL, 2017b).

15 Art. $9^{\circ}: \S 3^{\circ} \mathrm{O}$ contrato de trabalho temporário pode versar sobre o desenvolvimento de atividades-meio e atividZdes-fim a serem executadas na empresa tomadora de serviços.” (NR) (BRASIL, 1974).

16 O Projeto de Lei $\mathrm{n}^{\circ} 1.621 / 2007$ vedava a terceirização na atividade-fim, previa a necessidade de informação ao sindicato da categoria profissional sobre o projeto de terceirização da empresa, exigia um maior controle e fiscalização pela tomadora dos serviços, proibia qualquer forma de discriminação, trazia a responsabilidade objetiva e solidária no cumprimento de qualquer obrigação trabalhista e previdenciária, previa a possibilidade de vínculo direto com o tomador em caso de fraude e multa em favor do trabalhador pelo descumprimento da lei (BRASIL, 2007).

17 Vide dossiê bem detalhado da Central Única de Trabalhadores sob o título de Terceirização e desenvolvimento: uma conta que não fecha - dossiê acerca do impacto da terceirização sobre os trabalhadores e propostas para garantir a igualdade de direitos (CUT, 2014). Vide ainda o relatório do IPEA intitulado de Impactos da terceirização sobre a remuneração do trabalho no Brasil: novas evidências para o debate (CAMPOS, 2016). 
atingem não apenas as atividades laborais propriamente ditas, como também as condições de vida

do trabalhador. Nesse contexto, é preciso enfrentar a questão relativa às relações de poder e a contribuição do Estado e do direito para a produção e reprodução de seus efeitos práticos.

\section{PENSAR O ESTAdo E O DIREITO NA PRÁticA DA CONSERVAÇÃO DAS RELAÇÕES DE PODER: UMA ABORDAGEM SEGUNDO PIERRE BOURDIEU}

Se bem havendo limites legais e jurisprudenciais, a "terceirização" sempre avançou em suas práticas laborais. Agora, com o alargamento das possibilidades legais praticadas pela Administração Pública, combinada com a "desresponsabilização" do ente público nos casos de contratação terceirizada, a ampliação de seus efeitos são ainda mais concretas.

Para a Constituição, em consequência, a terceirização sem peias, sem limites, não é compativel com a ordem jurídica brasileira. As fronteiras encontradas pela experiência jurisprudencial cuidadosa e equilibrada para a prática empresarial terceirizante, mantendo esse processo disruptivo dentro de situações manifestamente delimitadas, atende, desse modo, o piso intransponível do comando normativo constitucional (DELGADO, 2015, p. 484).

O Estado é por natureza a instituição que reivindica, além da força física, a força simbólica, encarnando tanto a "objetividade" sob a forma de estruturas e de mecanismos específicos, quanto a "subjetividade" sob a forma de estruturas mentais, de esquemas de percepção e de pensamento (BOURDIEU, 2004b, p. 98).

Nesse contexto, é preciso afirmar a necessidade de se estabelecer as bases de um trabalho de ruptura com as pré-noções e os pressupostos baseados nas evidências comuns, como por exemplo, o tratamento da noção de Estado reduzido ao estudo da política.

Para Bourdieu (2004b) a intervenção arbitrária do Estado e os efeitos de suas escolhas são mobilizados e impostos à realidade e aos espíritos de modo naturalizado, porque ele sintetiza tanto interesses corporativos muito poderosos, quanto as próprias divisões e hierarquias sociais que a ele estão associadas.

Diante disso, é possível compreender o Estado como aquele que domina a produção simbólica, sentida pela conceituação sobre qual seja a função da administração pública e sobre quais as competências devem ser atribuídas a um funcionário público ${ }^{18}$, por exemplo. Daí verificarse a dificuldade de pensar a questão do Estado de forma atemporal e genérica, haja vista que esse pensamento é absolutamente associado à construção e à consolidação de uma visão particular, de acordo com interesses e valores, daqueles que produzem esse universo burocrático (BOURDIEU, 2004b).

Segundo Bourdieu (2004b, p. 98), apenas a reconstrução da gênese dos conflitos e dos

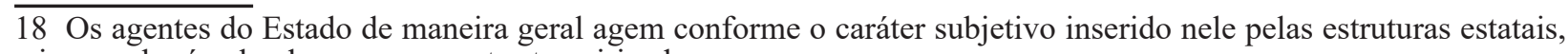
isso acabará valendo para os agentes terceirizados. 
confrontos, por meio de uma lógica propriamente histórica dos processos sociais, poderá ser capaz de recolocar sobre questionamento a "ocorrência ou incidência" do fato, em contraposição ao que "poderia ter ocorrido", a partir das possibilidades descartadas em relação ao fato ${ }^{19}$.

Portanto, o Estado é resultado de um processo de concentração e reprodução de diferentes tipos de poder (informação e cultura, etc) e de seus instrumentos de coerção (exército, polícia, fisco, direito, etc), em que a concentração desse metapoder justifica a mobilização das forças sociais em disputa (BOURDIEU, 2004b).

\subsection{Cultura e linguagem e o poder unificador do Estado}

No âmbito desse processo de unificação estatal, a cultura tem um papel essencial na homogeneização das formas de comunicação, desde os códigos de linguagens até as burocracias jurídicas. Ao mesmo tempo, através das classificações sociais e das distinções de classe, o Estado irá inscrever as estruturas sociais e impor seus princípios de visão e divisão comuns, contribuindo para a construção de uma noção de realidade social ${ }^{20}$ (BOURDIEU, 2004b, p. 105).

Essa definição forjada pelo Estado, ou pelas suas esferas administrativas, legislativa e judiciária, é sempre uma construção simbólica, mediada pela linguagem: a linguagem do "dizer" as coisas (sentido semântico) e do "fazer" as coisas (sentido pragmático). Isto quer dizer que ao discurso estatal compete interpretar o passado, definir o presente e prever o futuro, na medida em que o pré-estabelece, dizendo como ele "deverá ser".

Assim é que a eficácia desse discurso se dá pelas condições sociais privilegiadas em que o discurso é produzido, ou seja, a ordem simbólica apoia-se sobre a imposição de estruturas cognitivas aparentemente coerentes e sistemáticas ${ }^{21}$, estando em consonância com as estruturas objetivas do mundo. É esse acordo imediato e pré-reflexivo que liga, por todos os liames do inconsciente, à ordem estabelecida (BOURDIEU, 2004b, p. 118).

\subsection{Direito e as relações de poder}

Para esse autor, o direito é um desses microcosmos, um espaço (um campo) relativamente autônomo, dotado de leis próprias, sem jamais escapar às intervenções do macrocosmo que o envolve: o Estado. Sujeito a pressões internas ${ }^{22}$ e externas ${ }^{23}$, o "campo" jurídico manipula e

19 É por isso que a primeira parte deste trabalho foi dedicada a descrever o fenômeno social em questão, ou seja, a própria prática da terceirização e seus reflexos sociais e jurídicos.

20 Noções sociais como "estabilidade laboral", "direitos sociais" e a "desassociação" necessária à noção de "terceirização" e ao resultado quase naturalizado junto ao exercício das atividades da Administração Pública.

21 Objeto de apreciação do último item desse artigo.

22 No interior do campo jurídico, é a autoridade jurídica investida do poder de violência física e simbólica, legitimada pelo monopólio estatal, que produz e exerce, respectivamente, teoria e prática jurídicas. Essa posição privilegiada da autoridade jurídica em relação ao leigo, não afasta a possibilidade de conflitos internos de competência entre as próprias autoridades jurídicas e jurisdicionais (BOURDIEU, 2000, p.211).

23 Segundo Bourdieu (2002, p. 67), a sociedade é diferenciada e consiste em um conjunto de espaços relativamente autônomos, como o campo cultural, o campo político, o campo econômico, que se influenciam uns em relação aos outros. 
traduz a seu modo (por seus agentes e instituições, através de sua própria linguagem teórica) tais necessidades.

Outro seja, o direito deve ser visto como um "reflexo direto das relações de força existentes, em que se exprimem as determinações econômicas, e, em particular, os interesses dominantes, ou então, como um instrumento de dominação" (BOURDIEU, 2000, p. 210).

Assim é que o campo jurídico (político) é o espaço de concorrência pelo monopólio de "dizer o direito" ou a "boa ordem jurídica", no qual se confrontam agentes investidos de suas competências sociais e técnicas com sua capacidade socialmente reconhecida de interpretar um corpo de textos e de consagrar uma visão legítima da realidade social.

"Poder declarar e impor o direito" significa "poder construir" uma estrutura social objetiva, isto é, "poder (re) produzir" efeitos de adesão e de submissão de uma sociedade em relação a uma matriz unificada de concepções e percepções de mundo, em tempo e espaço determinados.

Desta forma, o direito contribui para a sua própria força simbólica, e, para a ação do conjunto dos mecanismos que permitem poupar-se o trabalho (faire l'économie) da reafirmação contínua das relações de força pelo uso declarado da força (BOURDIEU, 2006, p. 200), ou seja, o direito não somente instaura relações duradouras de dominação, como também dissimula tais relações, quando conserva as suas características desiguais ${ }^{24}$.

Neste aspecto, deve-se ressaltar as contribuições específicas da identificação da "autoridade" (jurídica/judicial) combinada à "forma” jurídica para dar cumprimento a essas funções.

A decisão judicial é uma “forma” jurídica atribuída à competência de um juiz ${ }^{25}$, que decide, ou não, o mérito ${ }^{26}$ da causa. Será através da decisão judicial que o magistrado decidirá de forma fundamentada quem "tem o direito e quem não o tem". Portanto, quando da propositura de uma "demanda", em que são descritas pretensões sociais com a intenção de obter uma satisfação judicial, é essencial que, ao final de um processo, a solução dada seja fundamentada no direito.

No entanto, o que se observa, sob uma perspectiva sociológica e externa ao direito, é que as decisões judiciais dificilmente escapam às influências externas, e raramente se baseiam única e exclusivamente em argumentos jurídicos, conforme se deveria supor, tomando como base o universalismo dos códigos processuais e materiais jurídicos ${ }^{27}$.

\section{O USO DA LINGUAGEM JURÍDICAE AANÁLISE DOS ARGUMENTOS DA DECISÃO DO RECURSO EXTRAORDINÁRIO 760.931/DF}

Nesse item, será analisado um conjunto de construções argumentativas extraído dos votos

24 As distinções sociais encontram-se aí, nesse universo, dissimuladas. O direito sacramenta as desigualdades sociais, impressas, no caso concreto, no espaço geográfico em que laboram terceirizados e os funcionários públicos. As relações jurídico-trabalhistas e administrativas definem o "lugar" de cada um na sociedade.

25 A competência do juiz é a autorização legal que essa autoridade estatal detém para decidir os conflitos levados à jurisdição do Estado, é a parcela de jurisdição que compete a cada órgão jurisdicional.

260 "mérito" aqui é entendido como as questões que serão tratadas e decididas em determinada demanda, incluindo tanto a ponderação de seus efeitos, como a razão de seu conteúdo.

27 A legislação vigente conceitua a sentença como sendo: "o pronunciamento por meio do qual o juiz, com fundamento nos arts. 485 e 487, põe fim à fase cognitiva do procedimento comum, bem como extingue a execução.” Portanto, o conceito de sentença resulta de uma análise conjunta dos arts. 203, § 1º 485 e 487 do Código de Processo Civil. 
proferidos pelos ministros do Supremo Tribunal Federal nas sessões de julgamento que deu provimento ao Recurso Extraordinário n ${ }^{0} 760.931 / \mathrm{DF}^{28}$. Este versou sobre a "responsabilidade da Administração Pública pelo inadimplemento das verbas trabalhistas no caso de terceirização de mão de obra", cujo conteúdo foi além da ratificação do posicionamento acerca da Ação Declaratória de Constitucionalidade- ADC n ${ }^{\circ}$ 16/DF, que havia declarado a constitucionalidade do artigo $71, \S 1^{\circ}$, da Lei ${ }^{\circ} 8.666 / 1993$, vedando a transferência automática de responsabilidade à Administração Pública da União contratante e transferindo para o trabalhador terceirizado o ônus da demonstração da falha da contratação e fiscalização do contrato.

$\mathrm{Na}$ ação originária, o Tribunal Superior do Trabalho havia mantido a responsabilidade da União quanto ao adimplemento das verbas trabalhistas, porque constatada a existência de culpa in vigilando, ou seja, pela falta de acompanhamento e fiscalização do contrato, aplicando a sua Súmula no 331, IV e V e a ADC nº 16/DF (BRASIL, 2017b).

Ocorre que a União, ora recorrente, sustentava que a aplicação do artigo $37, \S 6^{\circ}$, da Constituição Federal ao presente caso feriria o estabelecido no julgamento da ADC n ${ }^{\circ} 16 / \mathrm{DF}$, além de violar os artigos $5^{\circ}$, II ${ }^{29} \mathrm{e} 37$, caput, ${ }^{30}$ da Constituição, por consagrar obrigação contrária ao estabelecido no artigo $71, \S 1^{\circ}$, da Lei $n^{\circ} 8.666 / 1993$, e que a culpa deveria ser provada pela parte interessada (BRASIL, 2017b).

Para a realização dessa análise argumentativa, será tomado como ponto de partida, as noções quanto à função e ao funcionamento do direito em Bourdieu (2000, 2004a, 2004b), bem como os conhecimentos e as técnicas argumentativas, para o desenvolvimento do senso crítico, em Carraher (2008).

\subsection{Interpretação constitucional e a "ignorância da questão"}

Um argumento é um conjunto de afirmações que inclui pelo menos uma conclusão. Quem apresenta um argumento usa premissas, chamadas de evidências, para defender ou fundamentar sua conclusão. As funções dos argumentos são diversas e correspondem, na vida em sociedade, à realização de certos objetivos. Nesse sentido, a comunicação é instrumental e interessada, e não apenas uma forma de representar ou desenvolver o conhecimento (CARRAHER, 2008, p. 4).

$\mathrm{Na}$ análise do caso em exame, o Supremo Tribunal Federal (STF), nos termos do voto do ministro Luiz Fux, chegou à seguinte conclusão: "O inadimplemento dos encargos trabalhistas

\footnotetext{
28 Trata-se de recurso extraordinário proposto pela União em face de Priscila Medeiros Nunes e Evolution Administradora de Serviços Terceirizada Ltda. Tendo como relatora a Ministra Rosa Weber, seu voto foi acompanhado pelos ministros Edson Fachin, Luís Roberto Barroso, Ricardo Lewandowski e Celso de 1. No entanto, o voto vencedor foi o do ministro Luix Fux, seguido pelos ministros Marco Aurélio, Gilmar Mendes, Dias Toffoli, Cármen Lúcia e Alexandre de Morais. As informações trazidas abaixo foram extraídas com base nos votos dos ministros disponibilizados no sítio eletrônico www.youtube.com e nos informativos do STF de $\mathrm{n}^{\circ} 852,853,854,859$ e 862, tendo em vista que o acórdão ainda não foi redigido. (BRASIL, 2017a).

29 Art. $5^{\circ}$ Todos são iguais perante a lei, sem distinção de qualquer natureza, garantindo-se aos brasileiros e aos estrangeiros residentes no País a inviolabilidade do direito à vida, à liberdade, à igualdade, à segurança e à propriedade, nos termos seguintes: [...]II - ninguém será obrigado a fazer ou deixar de fazer alguma coisa senão em virtude de lei;[...] (BRASIL, 1988).

30 Art. 37. A administração pública direta e indireta de qualquer dos Poderes da União, dos Estados, do Distrito Federal e dos Municípios obedecerá aos princípios de legalidade, impessoalidade, moralidade, publicidade e eficiência e, também, ao seguinte: [...] (BRASIL, 1988).
} 
dos empregados do contratado não transfere automaticamente ao Poder Público contratante a responsabilidade pelo seu pagamento, seja em caráter solidário ou subsidiário, nos termos do art. 71, § $1^{\circ}$, da Lei no 8.666/93” (BRASIL, 2017b).

Observa-se que as afirmações estão organizadas para cumprir uma determinada função social, num dado momento, e, para produzir um efeito sobre certos receptores, no caso, a sociedade brasileira, que já acumula pesadas prestações tributárias sem a contra partida de serviços públicos de qualidade. Nesses termos, o argumento de que "manter o poder público como garantidor universal dos trabalhadores terceirizados" impactaria ainda mais os custos sociais distribuídos entre todos solidariamente.

O problema com essa espécie de orientação, segundo os aspectos pragmáticos da sentença, é que essa coleção de argumentos, uma vez posta, pode levar a confundir explicações com afirmativas convenientes ou agradáveis à sociedade como um todo, com efeitos extensíveis a todos os entes federados da Administração Pública para adiante da própria União, bem como repercutiria nos milhares de casos semelhantes que tramitam nos tribunais trabalhistas de todo o país ${ }^{31}$, além de outras dezenas de milhares que seriam evitados.

No exemplo apresentado, um leigo poderia ser levado a entender que a única solução possível seria a de manter a "responsabilidade pelo adimplemento das verbas trabalhistas ao trabalhador terceirizado" nas mãos da empresa prestadora de serviços, real contratante. Então a hipótese de solução passaria a ser travada em um outro campo de combate ${ }^{32}$, denominado: "juízo de ponderação entre os interesses em conflito."

A despeito da solução dada, havia no voto da Ministra Rosa Weber, relatora do RE, outros elementos a serem considerados. Segundo a Ministra, seria possível reafirmar a tese da ADC $n^{\circ}$ 16/DF, no sentido de que é vedada a transferência automática da responsabilidade para a Administração Pública, cumulando o reconhecimento da hipótese da chamada "culpa presumida" e do "princípio da aptidão da prova", passando para o ente público o ônus de comprovar que atuou de acordo com as prescrições legais. Nessa hipótese, a solução também compatibilizaria a "condição de hipossuficiência" do empregado terceirizado aos princípios da cooperação e da boafé típicos instrumentos do processo do trabalho (BRASIL, 2017).

De outra forma, percebe que, a observância única dos primeiros argumentos, em detrimento das alegações da relatora, bem contribuiu para uma dupla lesão do princípio da igualdade entre trabalhadores não terceirizados e terceirizados.

Ora, a "ausência de responsabilidade" é um argumento que visa obscurecer outras questões reais que mereceriam atenção de um receptor versado em direito. Ainda que a Constituição não seja realmente explícita sobre a garantia dos direitos dos trabalhadores terceirizados, não se

31 Essa decisão produzirá efeitos para em média cinquenta mil processos, que se encontravam suspensos.

32 Exemplo de campo heterônomo, o campo jurídico sofre constantemente influência de outros campos, como o político e o burocrático (BOURDIEU, 2000, p. 37). Se bem que haja uma divisão do trabalho própria ao campo jurídico, frequentemente observa-se a concorrência entre agentes jurídicos e não-jurídicos, em termos de funções e poder de decisão. A despeito dessa disputa, do resultado do bargaining power, o direito continuará a apresentar-se como um sistema exclusivamente jurídico, aquém e além da relação de forças que, de fato, o sanciona e consagra. 
pode esquecer que consagrou a dignidade da pessoa humana e os valores sociais do trabalho como princípios fundamentais (art. $1^{\circ}$, III e IV, CF), além do compromisso nacional contra toda e qualquer forma de discriminação (art. $3^{\circ}$, III e IV, CF). De modo específico, ainda se vislumbra a extensa gama de direitos sociais previstos para os trabalhadores em geral (art. 7\%/1, CF), incluindo servidores públicos (art. 37/41, CF).

Ademais, o $§ 6^{\circ}$ do artigo 37 da Constituição Federal prevê a "responsabilidade objetiva" da Administração Pública ao afirmar que "responderão pelos danos que seus agentes, nessa qualidade, causarem a terceiros, assegurando o direito de regresso contra o responsável nos casos de dolo ou culpa". A "teoria do risco administrativo" deve ser evocada em todas as situações, inclusive no caso de danos causados aos trabalhadores terceirizados.

Para Carraher (2008, p. 30) esse fechar os olhos diante da realidade pode assumir a forma da "ignorância da questão", quando as premissas são "ajeitadas" e oferecidas ao receptor de tal forma que elas se tornem consistentes entre si e com as crenças do emissor, qual seja: a de que não devem ser encontradas previsões quanto à responsabilidade do ente público no adimplemento das verbas trabalhistas dos trabalhadores terceirizados.

\subsection{A noção de "omissão eloquente" e de outros critérios de interpretação}

Outro ponto de necessário destaque do voto vencedor é a afirmação de que se o $\S 2^{\circ}$ do artigo 71 da Lei no 8.666/1993 previu expressamente que a "Administração Pública responde solidariamente com o contratado pelos encargos previdenciários resultantes da execução do contrato" (BRASIL, 1993), e, nesse caso, não caberia a responsabilidade de encargos trabalhistas. Segundo o Ministro Luiz Fux, tratar-se-ia de típico caso de "silêncio eloquente", ou seja, "se [o legislador] quisesse, teria feito o mesmo em relação aos encargos trabalhistas", e se "não o fez, é porque entende que a Administração Pública já afere, no momento da licitação, a aptidão orçamentária e financeira da empresa contratada" (BRASIL, 2017a).

Nesse contexto, é importante conhecer o conceito de falácia. Falácia é um erro de raciocínio que contamina a argumentação, tornando-a sem fundamento apropriado (CARRAHER, 2008, p. 27).

Dentre as denominadas falácias informais, estão as "falácias de relevância", nas quais o emissor apresenta evidências que não são apropriadas para avaliar as conclusões propostas. Entre os "truques argumentativos" dessa natureza, identificados por Carraher (2008, p. 31), está aquele denominado: "falácia da petição do princípio", em que o emissor inclui nas próprias premissas (1) e (2) ideias apresentadas como conclusões do mesmo argumento (3), como pode se verificar no voto do Ministro Luiz Fux:

[...] num primeiro momento eu entendo que já na contratacão o Estado tem. o poder público tem capacidade de fiscalizar, não custa nada incluir uma cláusula no edital, ou no contrato, que ponha esta fiscalizacão (1) e, se não fiscalizar, é infração do dever contratual, não precisamos ficar buscando 
solucão diversa (2), [...] mas eu vou me ater a solucão da ADC 16 e a ratio legis da Lei 9.032 que só criou responsabilidade solidária para encargos fiscais previdenciários e no mesmo momento que poderia ter erigido uma responsabilidade subsidiária não o fez (3)[...]. (CARRAHER, 2008, p. 31, grifo nosso).

Ao desempatar a votação, o ministro Alexandre de Moraes afirma que o artigo $71, \S 1^{\circ}$ da Lei no 8.666/1993 é "mais do que claro" ao exonerar o Poder Público nestes casos (BRASIL, 2017).

Assim é que, nas conclusões dos Ministros verificam-se a eliminação de outras formas de interpretação do ordenamento jurídico, como se a única solução fosse aquela fornecida exclusivamente pela interpretação gramatical, o que "nem sempre é suficiente para a interpretação adequada de um texto legal" (KRELL, 2014, p. 305).

Assim, visando buscar um entendimento que harmonizasse os valores envolvidos, os Ministros poderiam ter se valido desde as técnicas mais tradicionais para interpretar o direito, como a interpretação sistemática, teleológica e histórica, bem como, poderiam ter lançado-mão de técnicas mais contemporâneas, interpretando conforme os princípios constitucionais da "máxima efetividade", "razoabilidade", entre outros, recorrentemente utilizados pelo STF, quando julga conveniente.

No Estado Social, o Judiciário tem como função a garantia da supremacia da Constituição, e no caso do Brasil, que possui uma Carta dirigente, é necessário que se intervenha para preencher possíveis lacunas jurídicas às instituições tradicionais, sempre no intuito de responder às demandas da sociedade (KRELL, 2012, p. 177).

Para além, a Corte Suprema não levou em consideração a própria Lei no 8.666/1993, que em seu artigo $3^{\circ}$ prevê o respeito ao denominado "desenvolvimento nacional sustentável"33, como fundamento das contratações públicas. Ademais, também desconsiderou o argumento artigo 67 da mesma lei ${ }^{34}$, que já observa o poder/dever do ente público de fiscalizar os contratos administrativos de forma permanente, inclusive no tocante a violação dos direitos dos trabalhadores terceirizados ${ }^{35}$ (BRASIL, 2017).

Além disso, percebe-se que certas partes da ADC no 16/DF (BRASIL, 2011) foram descaracterizadas e (re)caracterizadas pelo voto vencedor do RE 760.931/DF, produzindo um

\footnotetext{
33 Segundo a Lei 8.666/1993 e seu art. 3․: “A licitação destina-se a garantir a observância do princípio constitucional da isonomia, a seleção da proposta mais vantajosa para a administração e a promoção do desenvolvimento nacional sustentável" e será processada e julgada em estrita conformidade com os princípios básicos do direito administrativo. O princípio do desenvolvimento nacional sustentável possui duas dimensões: uma ecológica, que visa a adoção de práticas ambientais adequadas; e outra econômico-social, que "consiste num processo de incremento de riqueza acompanhado da elevação da qualidade de vida" (JUSTEN FILHO, 2011).

34 Art. 67. A execução do contrato deverá ser acompanhada e fiscalizada por um representante da Administração especialmente designado, permitida a contratação de terceiros para assisti-lo e subsidiá-lo de informações pertinentes a essa atribuição.

35 Voto da Ministra Rosa Weber (BRASIL, 2017). Na mesma linha, o ministro Luís Roberto Barroso afirma que a fiscalizacão do ente público é uma obrigacão de meio e não de resultado, pode inclusive ser realizada por amostragem com apoio técnico do órgão de controle externo, que terá presunção relativa de razoabilidade, devendo notificar a empresa terceirizada em caso de descumprimento de suas obrigações, e na manutenção da irregularidade, deve promover ação de depósito, com a liquidação e o pagamento das parcelas devidas aos trabalhadores, com o devido abatimento dos valores da empresa conratada (BRASIL, 2017a).
} 
resultado bem diferente, com aparente superioridade entre critérios $^{36}$. Ora, a omissão do legislador,

não pode produzir um efeito mais concreto e abrangente, que todo o conteúdo principiológico sobre contratações públicas e proteção laboral, ao contrário, deve-se utilizar aquela que garantir a melhor interpretação em favor do empregado que presta serviço para a Administração.

\subsection{Do apelo à concepção do Estado "moderno e eficiente"}

Em muitos contextos sociais surgem "chavões" para transmitir com menor grau de resistência de ideias entre uma fonte de informação e seus receptores.

Esse é o caso do uso da expressão "moderna e eficiente", em oposição à noção "arcaica e ineficiente”, para qualificar a gestão pública (CARRAHER, 2008, p. 40).

Nesse sentido, foi o voto do ministro Alexandre de Moraes:

Elastecer a responsabilidade do poder público em contratos de terceirização parecer ser um convite para que se faça o mesmo em outras dinâmicas de colaboração com a iniciativa privada, como as concessões de serviços públicos. [...] A consolidação da responsabilidade do estado pelos débitos trabalhistas de terceiro apresentaria risco de desestímulo de colaboração da iniciativa privada com a administração pública, estratégia fundamental para a modernização do Estado. (BRASIL, 2017a, grifo nosso).

Assim, se o receptor não estiver predisposto a questionar as razões do uso de tais expressões, bem como o seu conteúdo, pode ser estimulado a ser receptivo a um determinado argumento. Nesse caso, o poder persuasivo destas expressões pode resultar em distorções flagrantes, como, por exemplo, ajudar a restringir a efetividade de direitos sociais e individuais consagrados na Constituição.

O chamado "modelo gerencial” de administração pública foi proposto, a partir da década de 90, como resposta ao mercado financeiro, que exigia além de um ajuste fiscal, a desregulamentação de direitos e a privatização de setores estratégicos do Estado (CASTRO, 2006).

Nesse sentido, o conteúdo burocrático da Constituição Federal passou a ser contestado com a incorporação dessas novas diretrizes gerenciais, que culminaram com a aprovação da Emenda Constitucional n. 19 de 1998, que estabeleceu a adoção do "princípio da eficiência" na administração pública brasileira.

Para Chiavenato, "eficiência" pode ser compreendida como uma medida normativa de utilização dos recursos num processo. "[...] A eficiência é uma relação entre custos e benefícios.

36 .Apesar da ementa similar, a ADC n ${ }^{\circ}$ 16/DF consignou de forma expressa a possibilidade de responsabilização em caso de "culpa in vigilando, patente, flagrante", abordou ainda questões como "conflito de normas no espaço" e cotejou o art. $71, \S 1^{\circ}$, da Lei $n^{\circ} 8.666 / 93$ com o art. $37, \S 6^{\circ}$, da CF, o que resultou na vedação da responsabilidade do Estado de "forma irrestrita", mas possibilitando a responsabilização a depender das provas no caso concreto. Já o RE $n^{\circ} 760 / 931 / \mathrm{DF}$ balizou o critério de apreciação da prova, invertendo-o em favor do trabalhador. Com isto, é o trabalhador terceirizado quem deverá comprovar que o Estado não licitou e/ou fiscalizou o contrato (BRASIL, 2017a). 
Assim, a eficiência está voltada para a melhor maneira pela qual as coisas devem ser feitas ou executadas (métodos), a fim de que os recursos sejam aplicados da forma mais racional possível [...] (CHIAVENATO, 1994, p. 70). Não tardaria para que esse recurso de expressão fosse associado à crença de que somente "a privatização, compreendida no seu sentido amplo, traria um consequente avanço eficiente aos serviços públicos" ${ }^{37}$.

Ao contrário do que se poderia crer, o que se pode observar é que, as "terceirizações" praticadas, em âmbito precário, além de pouco contribuir para a eficiência da prestação do serviço público, ainda agravam as condições das relações trabalhistas na Administração Pública (ver Item1).

Ademais, ressalta-se que a construção deste "apelo popular" não se deu de maneira isolada pelo órgão jurisdicional. O processo judicial não paira alheio aos movimentos da sociedade. Não por acaso, o discurso dos meios de comunicação será repetido pelo Poder Judiciário. Em todas as situações, as motivações passam ao largo da racionalidade.

No fim, o que se observa nos textos das decisões e dos textos jornalísticos é o uso do "apelo popular" como estratégia de defesa de certas evidências, ${ }^{38}$ através da associação entre as mesmas e as crenças comumente aceitas, que falsamente imprimem a ideia de imparcialidade e racionalidade (CARRAHER, 2008, p. 40).

No dizer de Mascaro (2013, p. 70), "não são apenas falsas consciências ou ideias extravagantes ao todo social nem, ainda, simples emanações ocasionais de deliberações estatais, mas, sim, práticas efetivas, enraizadas em relações sociais concretas".

Não que se sustente a transferência automática da responsabilidade à Administração Pública, porque isso poderia incentivar ao descumprimento de direitos laborais do contratante, mas, ao mesmo tempo, a tese vencedora não pode vir a contribuir com a precarização das relações trabalhistas.

A solução deveria ser compatível com os valores sociais previstos na ordem jurídica pátria, como consagrado nos votos dos ministros Rosa Weber e Luís Roberto Barroso, que previram a inversão do ônus de prova em caso de "falha da fiscalização em favor do empregado", bem como o "dever notificar e reter os pagamentos à prestadora de serviços" ${ }^{39}$, com o fim de saldar a dívida

37 Desconsiderando a natureza social, própria dos serviços públicos, adotaram-se as referências privadas, quase que exclusivamente econômicas, para aquela gestão, considerando que: eficiência fosse um conceito matemático: fosse a relação entre insumo e produto (input e output). Um administrador eficiente é o que consegue produtos mais elevados (resultados, produtividade, desempenho) em relação aos insumos (mão-de-obra, material, dinheiro, máquinas e tempo) necessários à sua consecução. Em outras palavras, um administrador é considerado eficiente quando minimiza o custo dos recursos usados para atingir determinado fim. (MEGGINSON et al., 1998, p. 11).

38 Não é incomum que os representantes da administração pública adotem esse discurso nos meios de comunicação: "nosso objetivo é buscar junto à sociedade um modelo de gestão mais eficiente e dinâmico, que desonere a prefeitura e traga modernidade ao equipamento", afirmou o secretário municipal de Desestatização e Parcerias". Informações no site: http://www.capital.sp.gov.br/noticia/prefeitura-de-sp-lanca-edital-para-receber-estudos-de-concessao-paracomplexo-do-pacaembu.

39 Neste sentido, são várias as decisões do Tribunal de Contas da União, como os acórdãos n 1.450/2011 e 964/2012, bem como a Instrução Normativa $n^{\circ} 05$ de 2017 da Secretaria de Logística e Tecnologia da Informação do Ministério do Planejamento, Orçamento e Gestão, em especial, o art. 65: Art. 65. Até que a contratada comprove o disposto no artigo anterior, o órgão ou entidade contratante deverá reter: I - a garantia contratual, conforme art. 56 da Lei no 8.666, de 1993, prestada com cobertura para os casos de descumprimento das obrigações de natureza trabalhista e previdenciária pela contratada, que será executada para reembolso dos prejuízos sofridos pela Administração, nos termos da legislação que rege a matéria; e II - os valores das Notas fiscais ou Faturas correspondentes em valor proporcional ao inadimplemento, até que a situação seja regularizada. Parágrafo único. Na hipótese prevista 
de pagamento com os trabalhadores.

\section{CONCLUSÃO}

Sob o ponto de vista exclusivamente econômico, a "terceirização" aumenta os lucros e as vantagens do empregador contratante, pois o aumento da jornada de trabalho se combina com a redução das remunerações. Se isso ocorre de um lado, de outro, tem-se um "trabalhador (contratado) de segunda classe", o qual, sob o ponto de vista social e ambiental, arca com todos os prejuízos e danos à sua qualidade de vida e de sua família.

Por esse prisma, o Estado atua por meio de suas estruturas, sob a forma do processo jurídico e da decisão judicial, e de sua estruturação, que se encontra impressa no conteúdo das leis e das decisões judiciais dos magistrados, para produzir e reproduzir as classificações mentais e percepções distintas da realidade. No caso concreto do Estado brasileiro, observa-se pelo menos desde a década de 90, uma clara inflexão à satisfação exclusiva das diretrizes do mercado financeiro, em que o projeto de administração pública se caracteriza pela solução econômica da "eficiência" gerencial.

Se bem que o resultado do RE n ${ }^{\circ}$ 760.931/DF tenha um final conhecido: “a irresponsabilidade automática da Administração Pública no tocante ao adimplemento das verbas trabalhistas dos trabalhadores terceirizados" (BRASIL, 2017), esse trabalho objetivou realizar algumas ponderações sobre uso da linguagem e da argumentação, dita jurídica, sobre as decisões judiciais. Dentre as constatações, está o problema do uso indistinto de "falácias" e de "apelos", usados no sentido de convencer o receptor e a sociedade sobre a veracidade dos fatos narrados e sobre a necessária legitimação de um determinado arbitrário social e cultural, muitas vezes obscurecido.

\section{REFERÊNCIAS}

BOURDIEU, Pierre. A produção da crença: contribuição para uma economia dos bens simbólicos. Porto Alegre: Zouk, 2006.

BOURDIEU. Entrevistado por Maria Andréa Loyola. Rio de Janeiro: Ed. UERJ, 2002.

BOURDIEU. O poder simbólico. 3. ed. Rio de Janeiro: Bertrand Brasil, 2000.

BOURDIEU. Os usos sociais da ciência: por uma sociologia clínica do campo científico. São Paulo: UNESP, 2004a.1

BOURDIEU. Razões práticas: sobre a teoria da ação. 5. ed São Paulo: Papirus, 2004b.

BRASIL. Constituição (1988). Constituição da República Federativa do Brasil. Disponível em: <http://www.planalto.gov.br/ccivil_03/constituicao/ConstituicaoCompilado.htm>. Acesso

no inciso II do caput, não havendo quitação das obrigações por parte da contratada no prazo de quinze dias, a contratante poderá efetuar o pagamento das obrigações diretamente aos empregados da contratada que tenham participado da execução dos serviços objeto do contrato. 
em: 8 maio 2017.

BRASIL. Decreto no 2.271, de 7 de julho de 1997. Dispõe sobre a contratação de serviços pela Administração Pública Federal direta, autárquica e fundacional e dá outras providências. 1997a. Disponível em: <http://www.planalto.gov.br/ccivil_03/decreto/d2271.htm>. Acesso em: 14 mai. 2017.

BRASIL. Decreto-Lei ${ }^{0}$ 200, de 25 de fevereiro de 1967. Dispõe sobre a organização da Administração Federal, estabelece diretrizes para a Reforma Administrativa e dá outras providências. Disponível em: <http://www.planalto.gov.br/ccivil_03/decreto-lei/Del0200.htm>. Acesso em: 9 maio 2017.

BRASIL. Lei $\mathbf{n}^{\mathbf{0}}$ 5.645, de 10 de dezembro de 1970. Estabelece diretrizes para a classificação de cargos do Serviço Civil da União e das autarquias federais, e dá outras providências. Disponível em: <http://www.planalto.gov.br/ccivil_03/leis/L5645.htm>. Acesso em: 9 maio 2017.

BRASIL. Lei no 6.019, de 3 de janeiro de 1974. Dispõe sobre o Trabalho Temporário nas Empresas Urbanas, e dá outras Providências. Disponível em: $<$ http://www.planalto.gov.br/ ccivil_03/leis/L6019.htm>. Acesso em: 12 maio 2017.

BRASIL. Lei $\mathbf{n}^{\mathbf{0}} \mathbf{7 . 1 0 2}$, de 20 de junho de 1983. Dispõe sobre segurança para estabelecimentos financeiros, estabelece normas para constituição e funcionamento das empresas particulares que exploram serviços de vigilância e de transporte de valores, e dá outras providências. Disponível em: <http://www.planalto.gov.br/ccivil_03/leis/L7102.htm>. Acesso em: 12 maio 2017.

BRASIL. Lei no 8.666, de 21 de junho de 1993. Regulamenta o art. 37, inciso XXI, da Constituição Federal, institui normas para licitações e contratos da Administração Pública e dá outras providências. Disponível em: <http://www.planalto.gov.br/ccivil_03/leis/L8666cons.htm>. Acesso em: 12 maio 2017.

BRASIL. Lei $\mathbf{n}^{\mathbf{0}} \mathbf{8 . 8 6 3}$, de 28 de março de 1994. Altera a Lei $\mathrm{n}^{\mathbf{0}}$ 7.102, de 20 de junho de 1983. Disponível em: < http://www.planalto.gov.br/ccivil_03/LEIS/L8863.htm>. Acesso em: 12 maio 2017.

BRASIL. Lei $\mathbf{n}^{\mathbf{0}} \mathbf{8 . 9 8 7}$, de 13 de fevereiro de 1995. Dispõe sobre o regime de concessão e permissão da prestação de serviços públicos previsto no art. 175 da Constituição Federal, e dá outras providências. Disponível em: <http://www.planalto.gov.br/ccivil_03/LEIS/L8987cons. htm>. Acesso em: 12 maio 2017.

BRASIL. Lei n⿳0 9.472, de 16 de julho de 1997. Dispõe sobre a organização dos serviços de telecomunicações, a criação e funcionamento de um órgão regulador e outros aspectos institucionais, nos termos da Emenda Constitucional no 8, de 1995. 1997b. Disponível em: < http://www.planalto.gov.br/ccivil_03/LEIS/L9472.htm>. Acesso em: 12 maio 2017.

BRASIL. Lei n⿳0 9.637, de 15 de maio de 1998. Dispõe sobre a qualificação de entidades como organizações sociais, a criação do Programa Nacional de Publicização, a extinção dos órgãos e entidades que menciona e a absorção de suas atividades por organizações sociais, e dá outras providências. Disponível em: <http://www.planalto.gov.br/ccivil_03/leis/L9637.htm>. Acesso em: 12 maio 2017. 
BRASIL. Lei no 9.790, de 23 de março de 1999. Dispõe sobre a qualificação de pessoas jurídicas de direito privado, sem fins lucrativos, como Organizações da Sociedade Civil de Interesse Público, institui e disciplina o Termo de Parceria, e dá outras providências. Disponível em: <http://www.planalto.gov.br/ccivil_03/leis/L9790.htm>. Acesso em: 12 maio 2017.

BRASIL. Projeto de Lei n. 1.621, de 12 de julho de 2007. Dispõe sobre as relações de trabalho em atos de terceirização e na prestação de serviços a terceiros no setor privado e nas sociedades de economia mista. Disponível em: <http://www.camara.gov.br/ proposicoesWeb/prop_mostrarintegra;jsessionid=382CA59CFBB7DB5832858CEB61B70AFC. proposicoesWebExterno1? codteor $=483435 \&$ filename $=P L+1621 / 2007>$. Acesso em: 15 maio 2017.

BRASIL. Supremo Tribunal Federal. Ação Declaratória de Constitucionalidade n⿳ 16/DF. Governador do Direito Federal. Relator: Ministro Cezar Peluso. DJe de 9 set. 2011.

BRASIL. Supremo Tribunal Federal. Ação Direta de Inconstitucionalidade n 1.923/DF. Partidos dos Trabalhadores - PT, Partido Democrático Trabalhista - PDT e Presidente da República, Congresso Nacional. Relator: Ministro Luiz Fux. DJe de 5 mar. 2015.

. Supremo Tribunal Federal. Recurso Extraordinário no 760.931/DF. União e Priscila Medeiros Nunes, Evolution Administradora de Serviços Terceirizada Ltda. Relatora: Ministra Rosa Weber. Informativos no 852, 853, 854, 859 e 862. Disponível em: <http://www.stf.jus.br/ portal/informativo/pesquisarInformativo.asp>. Acesso em: 16 maio 2017a.

BRASIL. Supremo Tribunal Federal. Terceirização: plenário define limites da responsabilidade da administração pública. Notícias STF. 30 mar. 2017b. Disponível em: <http://www.stf.jus.br/ portal/cms/verNoticiaDetalhe.asp?idConteudo=339613>. Acesso em: 17 maio 2017.

BRESSER-PEREIRA, Luiz Carlos. Reforma do Estado para a cidadania: a reforma gerencial brasileira na perspectiva internacional. 2. ed. Brasília: ENAP, 2011.

CAMPOS, André Gambier. Impactos da terceirização sobre a remuneração do trabalho no Brasil: novas evidências para o debate. Brasília: IPEA, 2016.

CARRAHER, David. Senso crítico: do dia-a-dia às ciências humanas. São Paulo: Cengage, 2008.

CASTRO, Rodrigo. Eficácia, eficiência e efetividade na administração pública. In ENANPAD, 2006, Salvador. Anais... Salvador, 2006.

CHIAVENATO, Idalberto. Recursos humanos na empresa: pessoas, organizações e sistemas. 3. ed. São Paulo: Atlas, 1994.

CUT. Terceirização e desenvolvimento: uma conta que não fecha - dossiê acerca do impacto da terceirização sobre os trabalhadores e propostas para garantir a igualdade de direitos. São Paulo: Central Única dos Trabalhadores, 2014.

DELGADO, Maurício Godinho. Curso de direito do trabalho. 14. ed. São Paulo: LTr, 2015.

DI PIETRO, Maria Sylvia Zanella. Parcerias na administração pública: concessão, permissão, franquia, terceirização, parceria público-privada e outras formas. 10. ed. São Paulo: Atlas, 2015. 
DIEESE. Departamento Intersindical de Estatísticas e Estudos Socioeconômicos. Terceirização e precarização das condições de trabalho: condições de trabalho e remuneração em atividades tipicamente terceirizadas e contratantes. São Paulo, 2017.

HARVEY, David. A produção capitalista do espaço. São Paulo: Annablume, 2005.

JUSTEN FILHO, Marçal. Desenvolvimento nacional sustentado: contratações administrativas e o regime introduzido pela 12.349. Informativo Justen, Pereira, Oliveira e Talamini, Curitiba, n. 50, abr. 2011. Disponível em: $<$ http://www.justen.com.br//informativo. php?\&informativo $=50 \&$ artigo $=1077 \& \mathrm{l}=\mathrm{pt}>$. Acesso em: 12 maio 2017.

KRELL, Andreas Joachim. Entre desdém teórico e aprovação na prática: os métodos clássicos de interpretação jurídica. Revista de Direito GV: São Paulo, v. 10, n. 1, p. 295-320, 2014.

KRELL, Andreas Joachim. Para além do fornecimento de medicamento para indivíduos - O exercício da cidadania jurídica como resposta à falta de efetivação dos direitos fundamentais sociais: em defesa de um ativismo judicial moderado no controle de políticas públicas. In: FEITOSA, Enoque (Org.) et al. O judiciário e o discurso dos direitos humanos. Recife: Ed. Universitária, 2012.

MASCARO, Alysson Leandro. Estado e forma política. São Paulo: Boitempo, 2013.

MEGGINSON, Leon C. et al. Administração: conceitos e aplicações. 4.ed. São Paulo: Harbra, 1998.

MELLO, Celso Antônio Bandeira de. Curso de direito administrativo. 30. ed. São Paulo: Malheiros, 2013.

Como citar: MARCHIONI, Alessandra; BORBA, Daniel Miranda. A contribuição da análise de custo-benefício na avaliação da eficiência de regras fundiárias do distrito federal. Revista do Direito Público, Londrina, v. 13, n. 3, p. 91-110, dez. 2018. DOI: 10.5433/24157-1081041.2018v13n3 p. 91. ISSN: 1980-511X.

Recebido em: 02/07/2017

Aprovado em: 12/11/2018 